\title{
KOMPARASI FILTER WARNA PADA SISTEM PELACAKAN WAJAH BERBASIS PARTIKEL FILTER
}

\author{
Budi Sugandi ${ }^{1}$, Sefna Riftilah ${ }^{2}$ \\ ${ }^{12}$ Jurusan Teknik Elektro / Politeknik Negeri Batam \\ Jalan Ahmad Yani, Batam 29461 \\ I'budi_sugandi@polibatam.ac.id, ${ }^{2}$ sefna.riftilah@yahoo.com
}

\begin{abstract}
Abstrak-Artikel ini bertujuan membandingkan filter warna RGB, HSL dan YCbCr dalam mendeteksi dan melacak wajah berbasis partikel filter. Citra wajah yang ditangkap kamera secara real time akan diproses menggunakan filter warna RGB, HSL, dan YCbCr. Citra wajah akan dideteksi dengan mengatur interval kombinasi tiap elemen warna dari filter warna yang digunakan. Setelah citra wajah berhasil dideteksi, proses selanjutnya adalah pelacakan wajah menggunakan partikel filter. Metode partikel filter terdiri dari beberapa tahap, diantaranya proses inisialisasi yang dilakukan dengan cara menyebar partikel secara acak di sekitar citra wajah, prediksi dan update partikel, resampling partikel dan proses estimasi berdasarkan posisi rata-rata partikel. Hasil pengujian menunjukkan perbandingan kesalahan pelacakan dengan jumlah partikel 50, 70 dan 100 pada sumbu $X$ dan $Y$ adalah $(3.30 ; 2.11),(2.62 ; 1.70)$ dan (1.34; 1.21) menggunakan filter RGB, $(3.72 ; 1.92),(2.50 ; 1.81)$ dan $(1.85 ; 1.42)$ menggunakan filter HSL, dan (12.97; 5.01), (23.07; 5.11) dan (25.51; 3.57) menggunakan filter YCbCr.
\end{abstract}

Kata Kunci— deteksi wajah, pelacakan wajah, filter warna, partikel filter

Abstract-The study aims to make comparison among RGB, HSL, and YCbCr color filters on detecting and tracking face image based on the particle filter. Face image is captured using the camera in real time and processed using RGB, HSL and $\mathrm{YCbCr}$ color filters. The face image is detected by adjusting combination interval of each color element of the color filter. After the face image is detected, the face tracking is done using the particle filter method. The particle filter method consists of several stages, such as initializing process which done by generating of randomized particle based on the normal distribution, particle prediction and update, resampling particle and the final stage the process is particle filter estimation which is based on the average position of the particles at the time of observation. This experimental results show the error of the sistem using number of particles 50, 70 and 100 on $X$ and $Y$ axis are (3.30; 2.11), (2.62; 1.70) dan (1.34; 1.21) using RGB filter, $(3.72 ; 1.92),(2.50 ; 1.81)$ dan $(1.85 ; 1.42)$ using HSL filter, dan $(12.97 ; 5.01),(23.07 ; 5.11)$ dan $(25.51 ; 3.57)$ using YCbCr filter.

Keywords - face detection, face tracking, color filter, particle filter

\section{PENDAHULUAN}

Teknologi pengolahan citra merupakan bidang yang berkembang sangat pesat saat ini, terutama dalam aplikasi deteksi dan pelacakan wajah. Berbagai aplikasi dikembangkan di bidang deteksi dan pelacakan wajah seperti sistem keamanan, absensi kehadiran, membuka kunci dan lain-lain. Masalah yang kompleks muncul dalam pengembangan aplikasi jika deteksi dan pelacakan wajah dilakukan menggunakan kamera secara real time. Salah satu masalah yang timbul adalah ketergantungan hasil deteksi terhadap cahaya, noise di sekitar objek dan juga kualitas kamera yang digunakan.

Untuk mengatasi berbagai masalah tersebut, beberapa studi telah dilakukan dengan mengembangkan berbagai metode. Metode deteksi wajah berdasarkan algoritma Viola-Jones dilakukan dengan menggunakan Cascade Classifier [1], [2]. Algoritma Viola-Jones mempunyai tiga tahapan yaitu integral image, metode AdaBoost dan cascade classifier. Metode ini banyak digunakan untuk pengenalan wajah dengan akurasi lebih dari $90 \%$. Metode Principal Component Analysis (PCA) digunakan untuk pengenalan wajah berdasarkan eigenface citra gambar yang akan dikenali dibandingkan dengan eigenface citra dalam data base [3]. Nilai terdekat menunjukkan kemiripan citra wajah dengan data base. Ciri khas wajah yang merupakan warna kulit dapat dengan mudah dibedakan dengan warna objek lainnya menjadi pertimbangan beberapa studi untuk mengembangkan algoritma deteksi dan pelacakan wajah menggunakan filer warna. Filter warna yang digunakan adalah filter warna RGB [4], HSL [5] maupun YCbCr [6]-[9]. Perbandingan hasil deteksi tiap filter warna telah dikembangkan untuk mengetahui akurasi masing-masing filter [10]. Artikel lainnya menggabungkan beberapa filter warna untuk mendapatkan hasil yang lebih akurat [11], [12]. Dengan berkembangnya kecepatan komputasi sistem, 
beberapa peneliti mengembangkan algoritma berdasarkan metode probabilitas untuk mendeteksi dan melacak objek. Salah satu algoritma yang digunakan adalah algoritma partikel filter [13]-[16]. Metode partikel filter didasarkan pada kemiripan suatu ciri Page | 85 objek dengan ciri yang dimiliki oleh partikel yang disebar di sekitar objek.

Berdasarkan penelitian dan pengujian yang telah dipaparkan di atas, dalam artikel ini akan dikembangkan sebuah aplikasi pendeteksian wajah dan pelacakan wajah yang menggabungkan algoritma filter warna dengan algoritma partikel filer secara real time dengan menggunakan kamera. Komparasi akurasi penggunaan filter warna akan diujikan dengan beberapa nilai partikel untuk mendapatkan hasil yang optimal.

Agar pembahasan lebih terstruktur, artikel ini disusun sebagai berikut. Bagian 2 akan menjelaskan teori pustaka penunjang penelitian. Bagian 3 akan menjelaskan metodologi yang digunakan dalam pendeteksian dan pelacakan wajah. Bagian 4, akan dipaparkan hasil pengujian dari masing-masing filter warna dan partikel filter termasuk analisa hasil pengujian yang telah dilakukan. Kesimpulan dan beberapa saran untuk perbaikan sistem ke depan disajikan dalam bagian 4 .

\section{DASAR TEORI}

\section{A. Filter Warna RGB, HSL dan $\mathrm{YCbCr}$}

RGB (Red, Green, Blue) adalah warna dasar objek yang merepresentasikan warna yang dipantulkan objek ke mata kita. Warna dasar RGB terdiri dari 3 kanal warna yang masing-masing mempunyai rentang warna 0-225. Nilai 0 menunjukkan warna hitam sedangkan nilai 255 menunjukkan warna merah atau hijau atau biru tergantung kanal warnanya. Ketika tiga kanal warna dasar tersebut dipadukan maka menghasilkan warna lain.

HSL (Hue, Saturation, Luminance) merupakan salah satu filter warna yang digunakan untuk membedakan satu bagian warna objek dari warna yang lainnya. HSL banyak digunakan untuk membedakan objek jika tampilan latar belakang yang berubah-ubah karena pengaruh dari cahaya. Filter warna HSL lebih mudah digunakan untuk membedakan objek satu dengan objek yang lainnya jika dibandingkan dengan filter warna RGB. Persamaan transformasi dari RGB ke HSL [14] pada Persamaan (1) :

$$
\begin{aligned}
r & =\frac{R}{255} ; g=\frac{G}{255} ; b=\frac{B}{255} \\
d & =\max (r, g, b)-\min (r, g, b) \\
L & =\frac{\max (R, G, B)+\min (R, G, B)}{2}
\end{aligned}
$$

$$
\begin{aligned}
& H= \begin{cases}0, & \text { if } d=0 \\
\frac{60(G-B)}{d}, & \text { if } \max =r \\
120+\frac{60(B-R)}{d}, & \text { if } \max =g \\
240+\frac{60(R-G)}{d}, & \text { if } \max =b\end{cases} \\
& S= \begin{cases}\frac{0,}{d}, & \text { if } L=0<0.5 \\
\frac{\max (r, g, b)+\min (r, g, b)}{d} & \text { if } L>0.5 \\
\frac{d-\max (r, g, b)+\min (r, g, b)}{2-6}\end{cases}
\end{aligned}
$$

Besarnya nilai dari tiap komponen warna HSL ini adalah sebagai berikut : $0 \leq H \leq 360^{\circ}, 0 \leq S \leq 1$ dan $0 \leq L \leq 1$

Filter warna $\mathrm{YCbCr}$ merupakan filter warna yang terdiri dari $\mathrm{Y}($ luminance $), \mathrm{Cb}$ (chrominance blue) dan $\mathrm{Cr}$ (chrominance red). Komponen $\mathrm{Y}$ diperoleh dari jumlah bobot dari RGB, sedangkan pada komponen krominan ( $\mathrm{Cb}$ dan $\mathrm{Cr}$ ) merupakan pengurangan suatu komponen luminan terhadap $\mathrm{B}$ dan $\mathrm{R}$. Berikut persamaan transformasi dari RGB ke YCbCr [17] dapat dilihat di Persamaan (2).

$$
\left[\begin{array}{c}
Y \\
C b \\
C r
\end{array}\right]=\left[\begin{array}{ccc}
0.299 & 0.587 & 0.144 \\
-0.159 & -0.332 & 0.050 \\
0.500 & -0.419 & -0.081
\end{array}\right]\left[\begin{array}{c}
R \\
G \\
B
\end{array}\right]
$$

Gbr. 1 merupakan perbandingan hasil pendeteksian citra wajah menggunakan filter warna RGB, HSL dan YcbCr.
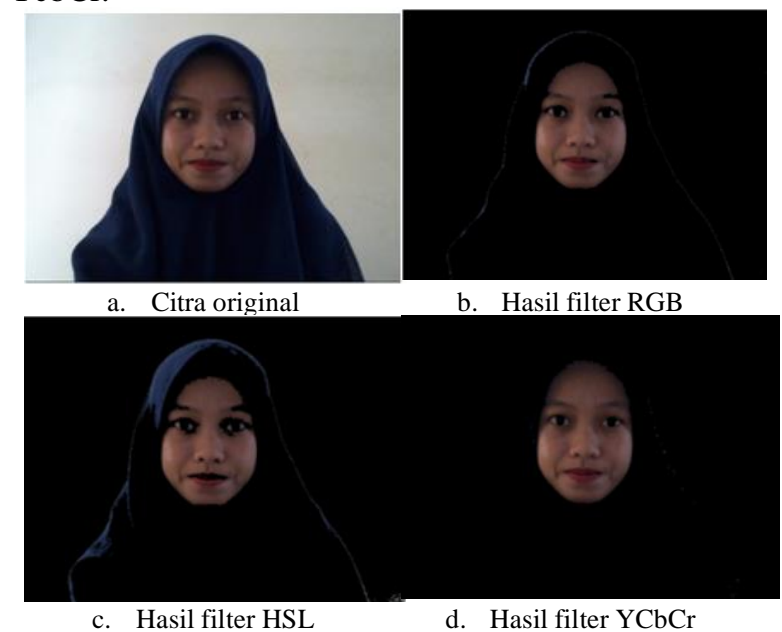

Gbr. 1 Hasil pendeteksian wajah dengan filter RGB, HSL dan $\mathrm{YCbCr}$ 


\section{B. Partikel Filter}

Penggunaan metode partikel filter lebih luas dibandingan dengan metode Kalman filter dengan adanya keunggulan partikel filter yang dapat digunakan pada sistem non-linear. Nilai estimasi dari

Page | 86 partikel filter didasarkan pada metode Monte Carlo [17]. Dalam proses estimasinya, partikel filter dibagi dalam dua langkah yaitu prediksi dan update. Prediksi dilakukan dengan menyebarkan partikel berdasarkan model pergerakan dari sampel (partikel) yang akan diuji. Update dilakukan dengan cara mengukur masing-masing bobot sampel berdasarkan model pengamatan yang diberikan. Model pengamatan ini dapat berupa jarak objek dengan objek referensi tertentu maupun histogram warna dari objek dengan histogram objek referensi.

Proses awal partikel filter dilakukan dengan menginisialisasi partikel secara acak dengan distribusi normal, kemudian partikel diprediksi berdasarkan model pergerakan sebuah objek yang dimodelkan dalam persamaan gerak objek. Proses pengamatan dilakukan dengan menggunakan jarak tiap partikel untuk mencari likelihood atau kemiripan partikel dengan objek referensi. Proses likelihood ini mengggunakan ciri warna dari objek yang akan dilacak Persamaan untuk mencari jarak tiap partikel dapat dilihat pada Persamaan (3). Kemudian berdasarkan dari nilai bobotnya akan dibuat perkumpulan partikel baru, dimana partikel yang memiliki bobot terendah akan hilang dan digantikan dengan partikel dengan bobot yang lebih besar.

$$
\begin{aligned}
& d_{x k}=\sqrt{{x_{k}{ }^{2}-x_{k-1}{ }^{2}}^{2}} \\
& d_{y k}=\sqrt{{y_{k}{ }^{2}-y_{k-1}{ }^{2}}^{2}}
\end{aligned}
$$

Dengan $d_{x k}$ dan $d_{y k}$ adalah jarak tiap partikel dengan posisi objek pada frame sebelumnya dalam koordinat $x$ dan $y$.

Tahap akhir dari proses partikel filter adalah melakukan estimasi pelacakan posisi objek berdasarkan rata-rata posisi partikel saat pengamatan. Proses estimasi posisi objek dapat dihitung menggunakan persamaan (4).

$$
\begin{aligned}
& x_{k}=\frac{1}{N} \sum_{i=0}^{N} x_{i}^{k} \\
& y_{k}=\frac{1}{N} \sum_{i=0}^{N} y_{i}^{k}
\end{aligned}
$$

Dengan $x_{k}$ dan $y_{k}$ adalah nilai koordinat $x$ dan $y$ hasil estimasi partikel partikel.

\section{METODE PENELITIAN}

\section{A. Diagram Alir Sistem}

Berdasarkan diagram alir pada Gbr. 2, langkah pertama yang dilakukan yaitu dengan menangkap wajah menggunakan kamera secara real time. Setelah itu dilanjutkan dengan proses deteksi wajah, jika citra wajah sudah terdeteksi maka akan dilanjutkan ke proses pelacakan wajah, tetapi jika area wajah belum terdeteksi maka sistem akan mendeteksi citra wajah kembali hingga wajah dapat terdeteksi. Setelah itu langsung ke proses pelacakan wajah, jika wajah berhasil terlacak maka proses selesai dan berhasil. Jika ingin deteksi wajah kembali, maka kembali ke proses pendeteksian wajah hingga berhasil melacak wajah kembali.

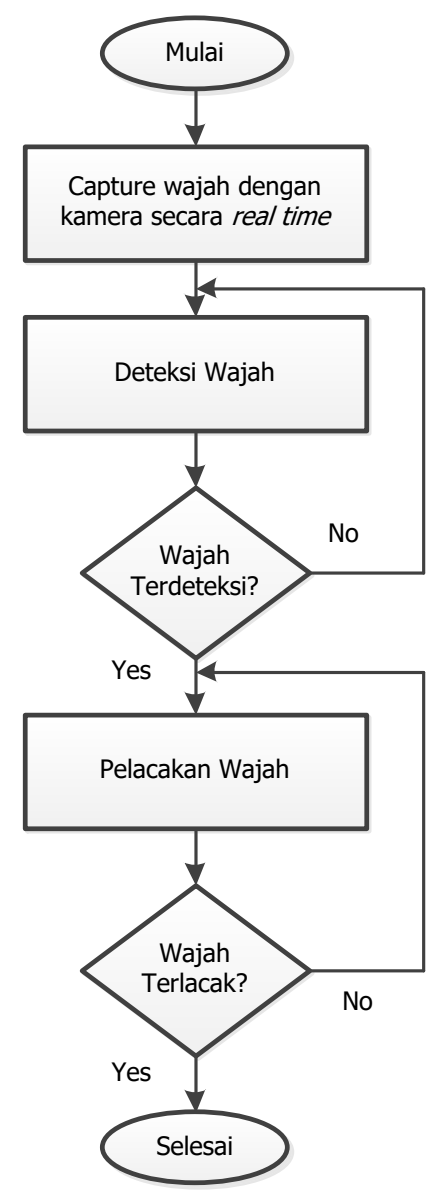

Gbr. 2 Diagram Alir Sistem

\section{B. Diagram Alir Deteksi dan Pelacakan Wajah}

Diagram alir deteksi dan pelacakan wajah ditunjukkan pada Gbr. 3. Proses deteksi wajah dapat dilakukan dari masukan citra wajah dan proses pengambilan citra. Setelah didapatkan citra wajah, selanjutnya akan difilter dengan menggunakan 3 filter warna (Gbr. 3a). Filter warna yang digunakan adalah filter RGB, HSL, dan YcbCr untuk mendapatkan area wajah yang diinginkan. 
Proses pelacakan wajah dilakukan dengan menggunakan partikel filter. Seperti ditunjukkan pada Gbr. 3b, langkah pertama pelacakan wajah adalah melakukan proses inisialisasi partikel yang dilakukan dengan cara penyebaran partikel filter secara acak di Page|87 sekitar objek wajah. Setelah proses inisialisasi dilanjutkan proses prediksi, kemudian proses update lalu resampling dan terakhir proses estimasi. Estimasi merupakan proses akhir dengan mencari bobot rata rata dari partikel filter tersebut.

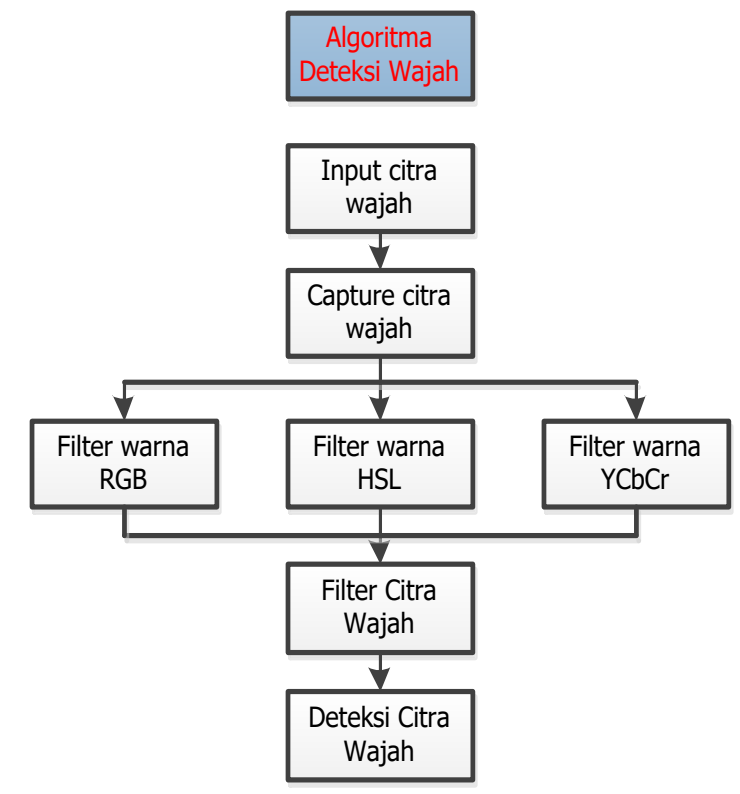

a. Deteksi wajah

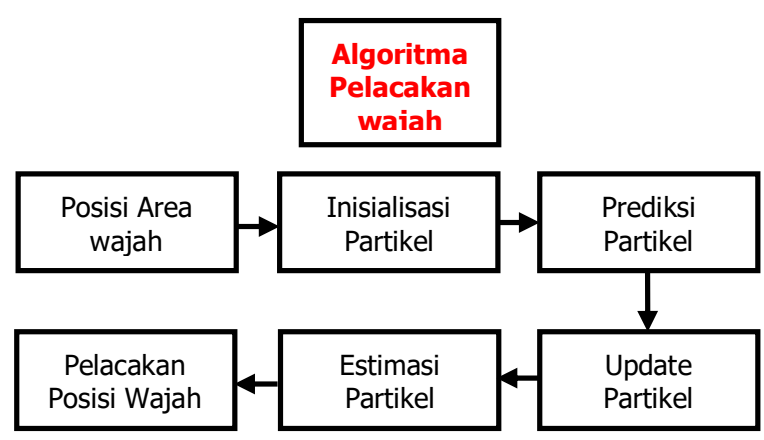

b. Pelacakan wajah

Gbr. 3 Diagram alir deteksi dan pelacakan wajah

\section{HASIL DAN PEMBAHASAN}

Pada tahap awal, citra wajah akan diproses secara defaut dengan menggunakan filter RGB. Filter RGB terdiri dari tiga kanal warna, yaitu warna merah, hijau dan biru untuk mendeteksi citra wajah. RGB merupakan warna asli dari tiap objek. Gbr. 4 menunjukan hasil deteksi wajah dengan filter RGB.

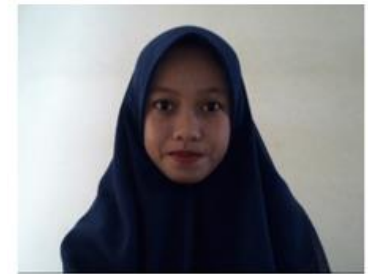

(a) Citra Asli

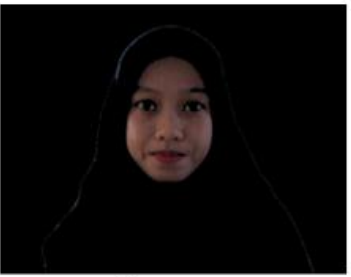

(b) Citra RGB
Gbr. 4 Hasil Deteksi dengan Filter RGB

Tahapan kedua citra wajah akan diproses dengan menggunakan filter warna HSL. Dibandingan dengan filter warna RGB, filter warna HSL lebih mudah digunakan untuk membedakan objek yang satu dengan objek lainnya yang akan dideteksi. Gbr. 5 menunjukkan hasil deteksi wajah menggjunakan filter warna HSL.

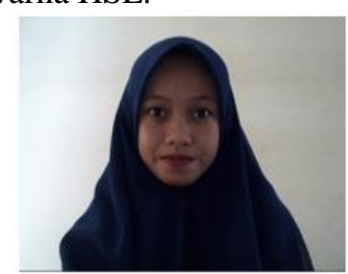

(a) Citra Asli

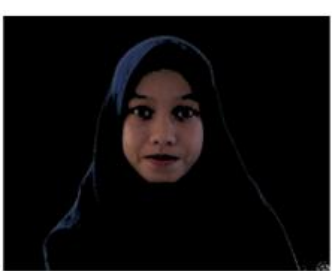

(b) Citra HSL
Gbr. 5 Hasil Deteksi dengan Filter HSL

Pada tahap selanjutnya citra wajah akan dideteksi dengan menggunakan filter warna YCbCr. Filter warna $\mathrm{YCbCr}$ dikenal dapat memisahkan antara komponen warna yang mengandung warna kulit dengan komponen warna lain. Sehingga filter warna YCbCr mampu dengan baik memisahkan antara citra warna pada wajah dengan warna latarnya. Gbr. 6 menunjukkan hasil deteksi wajah menggunakan filter warna $\mathrm{YCbCr}$.

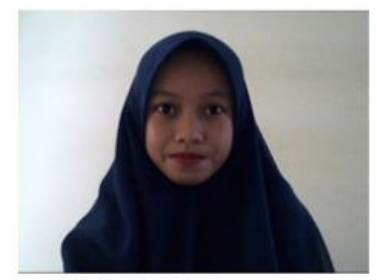

(a) Citra Asli

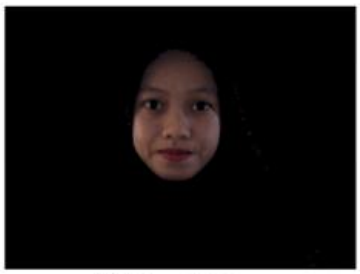

(b) Citra YCbCr
Gbr. 6 Hasil Deteksi dengan Filter $\mathrm{YCbCr}$

Proses pendeteksian citra wajah dengan menggunakan ketiga filter warna tersebut dapat dilakukan dengan pemilihan filter yang digunakan. Proses deteksi dengan 3 filter warna tersebut bertujuan untuk membandingkan hasil deteksi sehingga didapat hasil deteksi yang optimal. Dari hasil pengujian yang sudah dilakukan, dapat dilihat hasil deteksi wajah menggunakan filter $\mathrm{YCbCr}$ dapat mendeteksi posisi wajah dengan lebih baik.

Setelah proses deteksi wajah berhasil, maka dilanjutkan proses pelacakan pada citra wajah. Proses pelacakan dilakukan dengan pengujian hasil deteksi wajah sebanyak 9 kali dengan mengubah jumlah partikel yang tersebar yaitu 50, 70 dan 100 pada tiap 
filter yang akan diujikan. Hasil pengujian pelacakan wajah dari tiap filter warna disajikan pada Gbr.7-9 secara berturut-turut untuk hasil pengujian dengan jumlah partikel sebanyak 50, 70 dan 100 partikel. Pada tiap gambar, segi empat yang berwarna biru Page|88 menunjukkan hasil pelacakan wajah yang sesungguhnya, segi empat berwarna merah yang ditumpangi segiempat berwarna biru menunjukkan hasil estimasi pelacakan dengan partikel filter yang merupakan rata-rata dari posisi partikel sedangkan segi empat yang berwarna ungu menunjukkan hasil prediksi pelacakan wajah dari partikel filter. Dot berwarna merah merupakan posisi sesungguhnya dari wajah yang dilacak sedangkan tanda silang warna biru menunjukkan posisi estimasi rata-rata yang dihasilkan partikel filter.

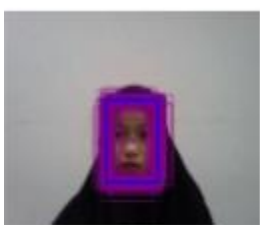

RGB

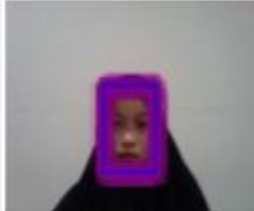

HSL

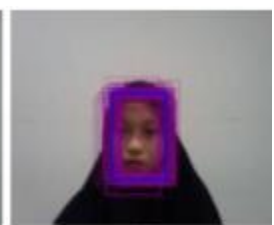

$\mathrm{YCbCr}$
Gbr. 7 Hasil Pelacakan dengan 50 Partikel

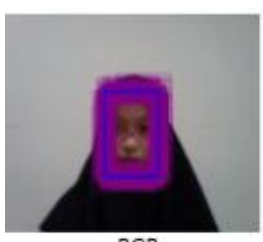

RGB

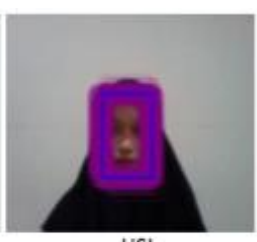

HSL

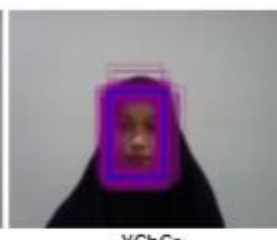

$\mathrm{YCbCr}$

Gbr. 8 Hasil Pelacakan dengan 70 Partikel

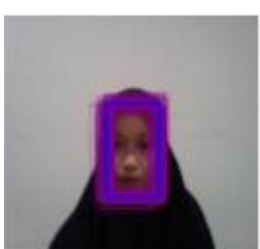

RGB

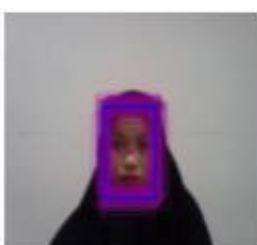

HSL

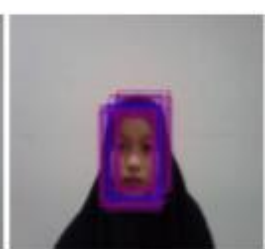

$\mathrm{YCbCr}$
Gbr. 9 Hasil Pelacakan dengan 100 Partikel

Gbr. 10-12 berturut turut menunjukkan perbandingan hasil pelacakan wajah menggunakan partikel filter dengan posisi posisi wajah yang sesungguhnya dengan filter warna RGB dengan 50, 70 dan 100 partikel. Garis berwarna biru menunjukan hasil pelacakan yang sebenarnya, garis berwarna jingga menunjukan hasil estimasi menggunakan filter. Hasil estimasi menggunakan 100 partikel menunjukkan tingkat kesalahan yang paling kecil dibanding hasil estimasi dengan jumlah partikel yang lain.

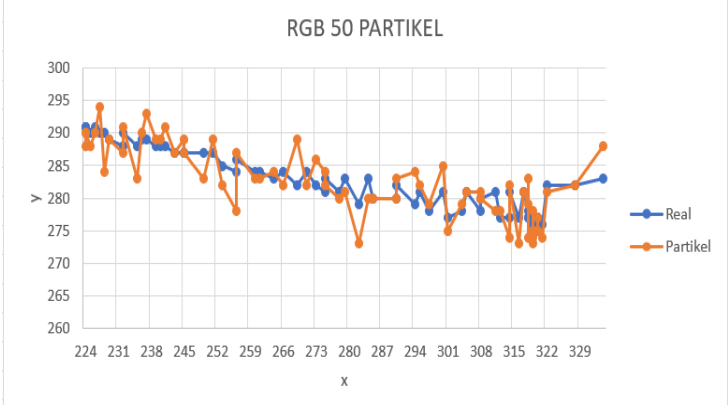

Gbr. 10 Pelacakan wajah menggunakan filter RGB dengan 50 Partikel

RGB 70 PARTIKEL

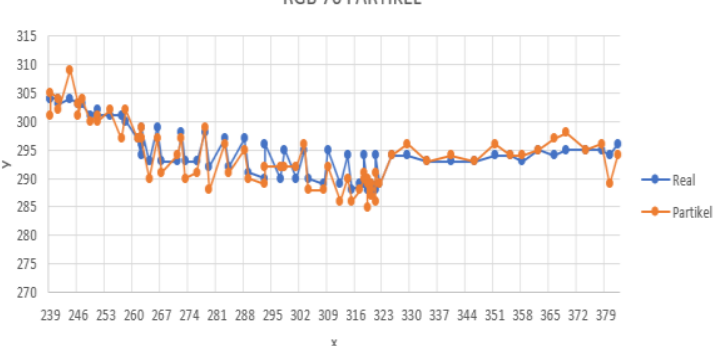

Gbr. 11 Pelacakan wajah menggunakan filter RGB dengan 70 Partikel

RGB 100 PARTIKEL

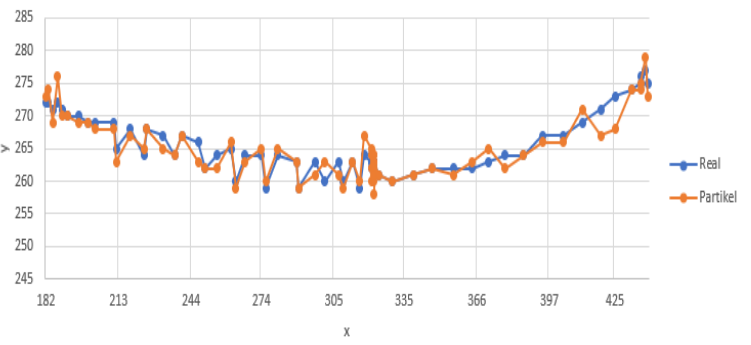

Gbr. 12 Pelacakan wajah menggunakan filter RGB dengan 100 Partikel

Gbr. 13-15 berturut turut menunjukkan perbandingan antara posisi wajah yang sesungguhnya dengan estimasi posisi wajah menggunakan partikel filter dengan filter warna HSL. Garis berwarna biru menunjukan hasil pelacakan yang sebenarnya, garis berwarna jingga menunjukan hasil estimasi menggunakan filter. Hasil pelacakan dengan menggunakan 100 partikel juga mempunyai nilai kesalahan yang paing kecil dibanding hasil pelacakan menggunakan jumlah partikel yang lain. 


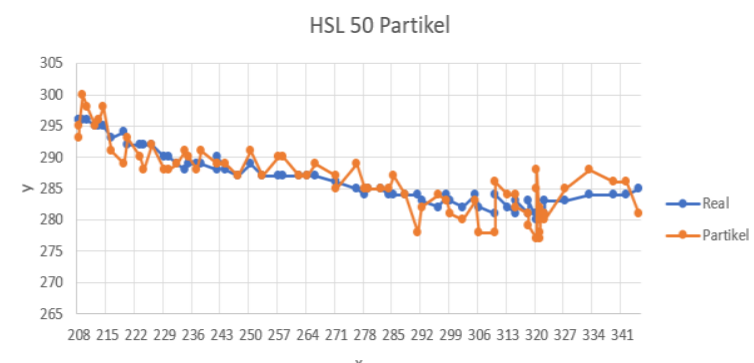

Gbr. 1 Pelacakan wajah menggunakan filter HSL dengan 50 Partikel

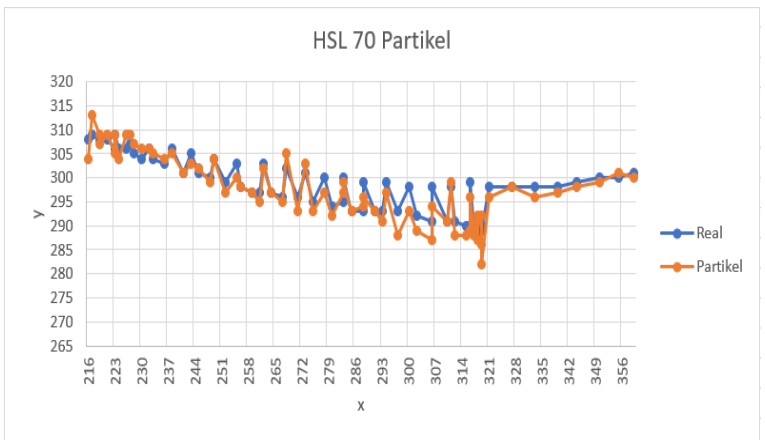

Gbr. 14 Pelacakan wajah menggunakan filter HSL dengan 70 Partikel

HSL 100 Partikel

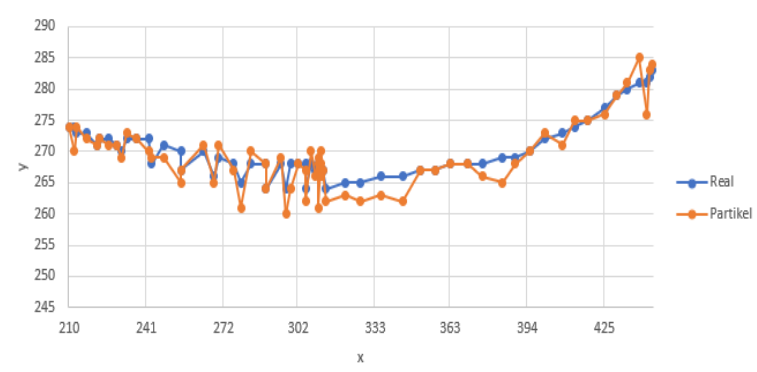

Gbr. 2 Pelacakan wajah menggunakan filter HSL

dengan 100 Partike

Gbr. 16-18 berturut turut menunjukkan perbandingan antara posisi wajah yang sesungguhnya dengan estimasi posisi wajah menggunakan partikel filter dengan filter warna $\mathrm{YCbCr}$. Garis berwarna biru menunjukan hasil pelacakan yang sebenarnya, garis berwarna jingga menunjukan hasil estimasi menggunakan filter. Hasil pelacakan dengan menggunakan 100 partikel juga mempunyai nilai kesalahan yang paing kecil dibanding hasil pelacakan menggunakan jumlah partikel yang lain.

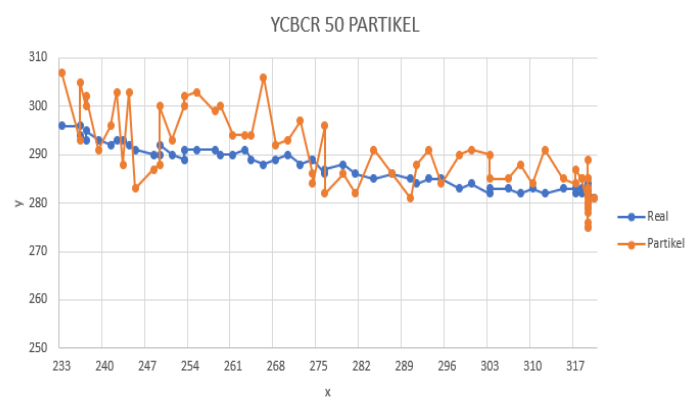

Gbr.16 Pelacakan wajah menggunakan filter $\mathrm{YCbCr}$ dengan 50 Partikel

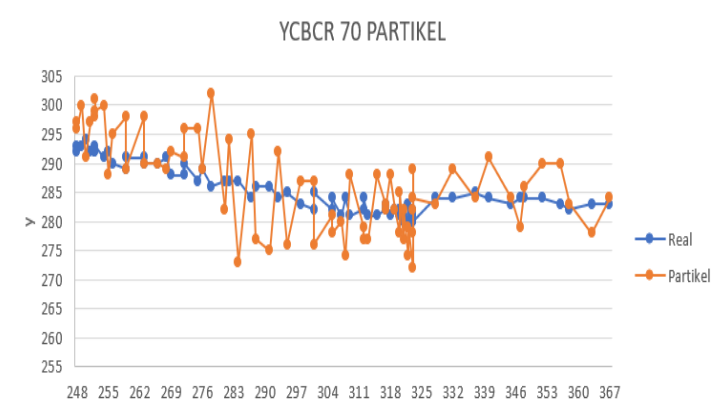

Gbr. 17 Pelacakan wajah menggunakan filter $\mathrm{YCbCr}$ dengan 70 Partikel

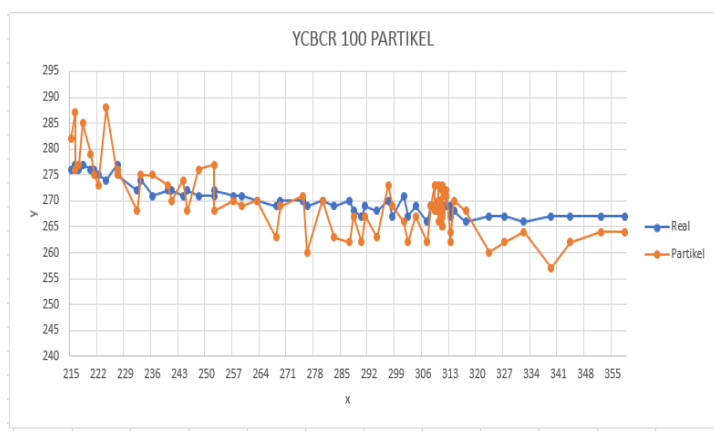

Gbr. 18 Pelacakan wajah menggunakan filter $\mathrm{YCbCr}$ dengan 100 Partikel

Nilai error hasil pelacakan diperoleh dari perbedaan posisi wajah sebenarnya dengan posisi hasil estimasi partikel filter ditunjukkan pada TABEL I. Dari TABEL I terlihat bahwa masing-masing filter warna yang digunakan mempunyai nilai error di sumbu $X$ lebih besar dibandingkan nilai error di sumbu $Y$. Hal ini dikarenakan adanya pergerakan posisi wajah di sumbu $X$ lebih dinamis dibanding pergerakan di sumbu $Y$. Besarnya pergerakan mempengaruhi nilai estimasi partikel filter sehingga pergerakan yang besar memunculkan error yang besar. Selain itu, dari pengujian yang telah dilakukan dapat dilihat bahwa nilai error terbesar diperoleh pada pelacakan wajah yang dideteksi menggunakan filter warna $\mathrm{YCbCr}$. 
TABEL I.

PERBANDINGAN ERROR TERHADAP JUMLAH PARTIKEL

\begin{tabular}{|c|c|c|c|c|}
\hline & \multirow{2}{*}{$\begin{array}{l}\text { Filter } \\
\text { Warna }\end{array}$} & \multirow{2}{*}{$\begin{array}{l}\text { Jumlah } \\
\text { Partikel }\end{array}$} & \multicolumn{2}{|c|}{ Error (piksel) } \\
\hline & & & Sumbu X & Sumbu Y \\
\hline \multirow[t]{9}{*}{ Page 190} & \multirow{3}{*}{ RGB } & 50 & 3.30 & 2.11 \\
\hline & & 70 & 2.62 & 1.70 \\
\hline & & 100 & 1.34 & 1.21 \\
\hline & \multirow{3}{*}{ HSL } & 50 & 3.72 & 1.92 \\
\hline & & 70 & 2.50 & 1.81 \\
\hline & & 100 & 1.85 & 1.42 \\
\hline & \multirow{3}{*}{ YCbCR } & 50 & 12.97 & 5.01 \\
\hline & & 70 & 23.07 & 5.11 \\
\hline & & 100 & 25.51 & 3.57 \\
\hline
\end{tabular}

\section{KESIMPULAN}

Penelitian ini telah mengembangkan sistem pendeteksian citra wajah meggunakan filter warna RGB, HSL, dan YCbCr serta melakukan proses pelacakan wajah menggunakan partikel filter. Sistem yang dikembangkan telah berhasil mendeteksi dan melacak wajah menggunakan partikel. Hasil pengujian menunjukkan bahwa hasil deteksi wajah dengan menggunakan filter warna $\mathrm{YCbCr}$ terlihat lebih sempurna dibandingkan dengan hasil deteksi wajah menggunakan filter warna RGB dan HSL. Hasil pelacakan dengan menggunakan 100 partikel mempunyai nilai kesalahan yang paing kecil dibanding hasil pelacakan menggunakan jumlah partikel yang lain. Hasil pelacakan wajah dipengaruhi oleh besarnya pergerakan objek, semakin besar pergerakannya hasil estimasi pelacakan wajah memberikan nilai error yang lebih besar.

Penelitian ini yang telah menampilkan sistem pendeteksian dan pelacakan wajah dengan melakukan komparasi penggunaan filter warna RGB, HSL dan YcbCr dengan jumlah partikel 50, 70 dan 100. Penelitian ini akan menambah referensi bagi para peneliti lain dalam berinovasi terutama di bidang biometric, computer vision, surveillance system dan lain lain. Untuk penelitian selanjutnya akan dicoba untuk mendeteksi dan melacak multi wajah dengan melihat kemampuan komputasi dan kecepatan proses dari pratikel filter. Filter warna dapat dikombinasikan antara filter warna RGB, HSL dan YCbCr untuk mendapatkan hasil yang optimal. Penghitungan kemiripan partikel filter dapat ditambahkan dengan menghitung histogram kombinasi warna dari objek yang terdeteksi..

\section{REFERENSI}

[1] P. Dwisnanto, B. Teguh dan B. Winduratna, "Sistem Deteksi Wajah dengan Menggunakan Metode Viola-Jones",
Proceedings Seminar Nasional Science, Engineering and Technology, pp. 1-5, 2012.

[2] S. Hardianti, B. Sugandi dan A.D. Futra, "Face Recognition and Smile Detection as an Appraisal of Customer Satisfaction Instrumen",. Proceedings of the 2018 International Conference on Applied Engineering, ICAE 2018, pp. 1-6, 2018. https://doi.org/10.1109/INCAE.2018.8579368

[3] S. Salamun dan F. Wazir, "Rancang Bangun Sistem Pengenalan Wajah Dengan Metode Principal Component Analysis", RABIT: Jurnal Teknologi Dan Sistem Informasi Univrab, 1(2), 61-77, 2016

[4] C. Dutta dan R. Singh, "Automatic Face Detection Using RGB Color Model for Authentication", International Journal of Soft Computing and Engineering (IJSCE), 5(5), pp. 70-73, 2015.

[5] S. H. Tsai dan Y. H. Tseng, Y. H, "A novel color detection method based on HSL color space for robotic soccer competition", Computers and Mathematics with Applications, 64(5), 1291-1300, https://doi.org/10.1016/j.camwa.2012.03.073

[6] E. Li dan X. Yihong, X, "Face Detection Based on Improved Color Space of YCbCr", IOP Conference Series: Materials Science and Engineering, 439, 32075,2018. https://doi.org/10.1088/1757-899X/439/3/032075

[7] D. Dandotiya, Y. Tayal, P. Kumar, dan D. Singh, "Human Face Detection By YCbCr Technique", International Journal of Emerging Technologies in Computational and Applied Sciences (IJETCAS ), 6(3), 243-247, 2013.

[8] B. Sugandi, S. Octaviani, dan N.Pebrianto, "Visual trackingbased hand gesture recognition using backpropagation neural network", International Journal of Innovative Computing, Information and Control, 16(1), 301-313, 2020. https://doi.org/10.24507/ijicic.16.01.301

[9] R. Wijanarko, dan N. Eko, "Deteksi Wajah Berbasis Segmentasi Warna Kulit Menggunakan Ruang Warna Ycbcr \& Template Matching",. Jurnal Ilmiah Cendekia Eksata, 2(1), $1-6,2017$.

[10] S. Kolkur, D. Kalbande, P. Shimpi, . Bapat dan J. Jatakia, "Human Skin Detection Using RGB, HSV and $\mathrm{YCbCr}$ Color Models", Advances in Intelligent Systems Research, 137, 324-332, 2017..https://doi.org/10.2991/iccasp-16.2017.51

[11] T. Afirianto, "Model Warna HSCbCrAB untuk Deteksi Kulit Menggunakan PCA-kNN", Inform: Jurnal Ilmiah Bidang Teknologi Informasi Dan Komunikasi, 2(2), 49-54, 2017.

[12] J.V. Akhila, G. P. Basheer, "Advanced Hybrid Color Space Normalization for Human Face Extraction and Detection", International Journal for Scientific Research \& Development, 1(4), 1043-1053, 2013

[13] A. Johari, A, Budi dan P. Benny, "Klasifikasi Kepadatan Lalu Lintas Berbasis Multitracking Object Dengan Menggunakan Metode Particle Filter", Proceeding of Engineering, 64246431, 2015.

[14] B. Sugandi, B, "Deteksi dan Pelacakan Wajah Berdasarkan Warna Kulit Menggunakan Partikel Filter", Jurnal Rekayasa Elektrika, 14(2), 2018.

[15] T. Wang, W. Wang, H. Liu dan T. Li, "Research on a face real-time tracking algorithm based on particle filter multifeature fusion", Sensors, 19(5), 2019. https://doi.org/10.3390/s19051245

[16] D. Yang, "Face Tracking Based on Particle Filtering and $\alpha-\beta$ $\gamma$ Filtering", Applied Mechanics and Materials, 2306-2309, 2014. https://doi.org/10.4028/www.scientific.net/AMM.651653.2306

[17] L. Mihaylova, A. Y. Carmi, F. Septier, A. Gning, S. K.Pang, dan S. Godsill, "Overview of Bayesian sequential Monte Carlo methods for group and extended object tracking", Digital Signal Processing: A Review Journal, 25(1), pp. 1-16, 2014, https://doi.org/10.1016/j.dsp.2013.11.006 